American Journal of Economics and Business Administration 2 (2): 153-156, 2010

ISSN 1945-5488

(C) 2010 Science Publications

\title{
From Subhiksha (Prosper) To Iksha (Perspire): The Topsy-Turvy Story of Indian Retail Business Model
}

\author{
${ }^{1}$ H.M. Jha Bidyarthi, ${ }^{2}$ Ashish K. Srivastava, ${ }^{1}$ P.V. Bokad and ${ }^{1}$ Mayur A. Dande \\ ${ }^{1}$ Department of Business Administration and Research, \\ Shri Sant Gajanan Maharaj College of Engineering, Shegaon, Buldhana, Maharashtra, India \\ ${ }^{2}$ Institute of Management, Pt. Ravishankar Shukla University, Raipur, Chattisgarh, India
}

\begin{abstract}
Problem statement: To examine the factors that led to inception, high growth and sudden closure of Indian business ventures in upcoming sectors in a short span of less than 10 years. Approach: An IITian and an IIM-A grad (India's top notch academic institution) set up one of the largest Indian retail chain named Subhiksha Trading services Pvt. Ltd. in 1997 on an Indian business model that opened 1600 outlets in 10 years time across the country and proved a great hit for others to follow suit. This was based on the estimated $\$ 350$ billion Indian retail market of which organized retail accounts for only $6 \%$ of the total market. Suddenly it found itself cash strapped heading for closure of its outlets and perspiring for obtaining funds to revive it. It left many lessons for Indian organized retail sector to draw which this study attempted to bring forth. Results: The debt financers raised their eye brows against Subhiksha's enterpreneur and a debt restructuring plan is ensuing to revive it indicating severe deficiency in the capitalization plan of Subhiksha. Conclusion: The management of an organization must never oversight its invigorating weaknesses when the growth occurs rapidly during its introduction stage itself on account of favorable circumstances in the environment. The case of Subhiksha studied here is an illustrative lesson of failure of a sound business model due to this oversight.
\end{abstract}

Key words: Discount retailer, learning curve, multi-locational stores, capital structure

\section{INTRODUCTION}

Indian retail market is estimated to be at $\$ 350$ billion and organized retail accounts for $6 \%$ of the total market. So all the Biyani's, Ambani's and the Birla's (some of the large Indian business houses) are sharing the $6 \%$ pie so far. With such a huge opportunity anybody would like to enter the retail market. Both domestic and foreign retail players are interested in investing in Indian retail story (Vadlamani, 2009). The results have been, however, mixed so far but there are trends if looked more closely. The present study picks up the case of one such retail business-Subhiksha Trading Services Pvt. Ltd.-which emerged on this industrial scene with much hype and crashed with much more noise leaving a number of lessons behind to learn.

The promoter: Not many IITians and IIM grads think the way Mr. R. Subramanian, Subhiksha managing director, thinks as confessed by him in an interview (Warrier, 2007), "Going to the US never fascinated me. I preferred doing something in front of my own people rather than going to a foreign land because this gives you more satisfaction and recognition. And the sense of achievement is far greater than doing the same thing in a far-off land". He further opines, "India is your country and you will get as much opportunity as anybody else. If you don't do well here, you have only yourself to blame". (Warrier, 2007)

Initially, Mr. R. Subramanian got interested in the investment bank department of Citi Corp and he was one among the three who were recruited by them from IIM-A. After working there for 3-4 weeks, he realized that that was not where he wanted to work. He felt as if he was cut off from the world and living in a world of trading. He felt he was doing more and more of the same and earning more and more money. That was not what he wanted to do in life. I and He resigned from Citibank and came down to Chennai to join Enfield which had given him an offer when he was a student of IIM-A. It was a manufacturing company which had all spectrums of job. Mr. Subramanian was with Enfield for two years from 1989-91(Warrier, 2007).

Corresponding Author: H.M. Jha Bidyarthi, Department of Business Administration and Research, Shri Sant Gajanan Maharaj College of Engineering, Shegaon, Buldhana, Maharashtra, India 
Entrepreneurial Endeavour: The thought of doing something on his own came to Mr. Subramanian's mind in 1989 itself. But there were no Venture Capitalists (VCs) to fund his ideas in those days. There was no precedent in his family for him to dream of becoming an entrepreneur. His father used to work for the Reserve Bank of India and his brothers too were in government service. His cousins, after studying at various IITs, went abroad.

One day Mr. Subramnain talked to Mr. Viswanathan of Enfield who had got him into Enfield, "I wanted to start a company of my own". Mr. Viswanathan asked him from where was he going to get the money? Mr. Subramanian had no idea. Mr. Subramanian told Mr. Viswanathan that he would figure out. Mr. Viswanathan then told Mr. Subramanian that he would give him money to set up the company and Mr. Subramanian would run it for Mr. Viswanathan. As long as he could run the company, it was fine with Mr. Viswanathan.

Viswapriya-the asset securitization firm: $\mathrm{Mr}$. Viswanathan provided Mr. Subramanian with the money as promised with which Mr. Subramaniane set up his first company called Viswapriya in 1991. Mr. Subramanian got a galaxy of very good people on board. He basically did three things. He bought debentures from thousands of people who had them in very small numbers, he then consolidated them as 0.1 million (100000) or 0.2 million (200000) debentures and, finally he invested in mutual funds. The investors got a monthly income. Every time the money went to millions of investors, it went from Viswapriya and that way the company's name became popular. It was a good business to start and Viswapriya was the pioneer in it. (Warrier, 2007)

The big breakthrough nationally came in 1994 when Viswapriya started a new product IPO financing, which it called as Prime Advancing. The company created the first loan anywhere in the world for a guy who applied for shares without collateral, without guarantee. This industry and Viswapriya, both, boomed. Customers were making tons of money and Viswapriya was also making tons of money. So it was a win-win situation for everybody. In 1994-95, Viswapriya lent $\$ 40$ million. In 1995-96, it lent \$ 240 million. The net profit of the company zoomed to around $\$ 5$ million (Warrier, 2007). Of course, competition came soon.

The twist: The stock market collapsed in 1996. This compelled Mr. Subramanian to switch over from asset securitization to some other business in 1997. He made a study of two areas: Software and retail. Between software and retail, he thought it was a bit late for software as Satyam, Infosys, Wipro and TCS had already established by then. He didn't want to be a small and late entrant. In retail, he would be one of the early entrants, so he would have the learning curve much to his advantage.

Subhiksha-the largest Indian retail chain: $\mathrm{Mr}$. Subramanian allocated a $\$ 1$ million corpus to it and entered the retail business. There was a lot of thought process behind it. He wanted to attract not the top end customer but the aam aadmi. From his research of three months, he found that consumers prefer buying groceries from closer home. So, he decided to set up $1000 \mathrm{ft}^{2}$ shops all across the city and not a $10000 \mathrm{ft}^{2}$ big store at one location in Chennai. He decided to sell branded products at a lower price. He looked at all sorts of names and finally he chose the Sanskrit word Subhiksha (prosperity) because it reflects the Indian ethos and it is a word that can be understood all over India. What he was trying to do was different from the western model (Warrier, 2007). There was truly an Indian retail business model in place. The theme was, why pay more when you can get it for less at Subhiksha?

In March, 1997, Discount retailer Subhiksha Trading Services Ltd, opened its first store in Thiruvanmiyoor in Chennai with an investment of around \$ 8-10,000 that increased to 1600 outlets selling groceries, fruits, vegetables, medicines and mobile phones by the year 2008 with a turn over of $\$ 451$ million in this financial year. It further had plans to increase the number of outlets to 2200 stores across the country with additional investment of \$ 200 million by end 2009. "Subhiksha has focused on opening stores region by region. It is important to achieve deep penetration to compete with neighborhood kirana stores" (Venkataraman, 2007). Subhiksha now has the pan Indian presence with stores across Delhi, UP, Punjab, Haryana, Gujarat, Maharashtra, AP, Karnataka, Kerala and TN. Today, it is a multi-locational, professionally managed and vibrant organization. The retail chain has seen a considerable growth by offering goods at cheaper rates and there by increasing its customer base. It is also dubbed as India's largest retail chain. Vision to deliver consistently better value to Indian consumers, has guided Subhiksha to deliver savings to all consumers on each and every item that they need in their daily lives, 365 days a year, without any compromise on quality of goods purchased.

According to the profit and loss account of the company for the fiscal year ended 31 March, 2007, its income and net profit were $\$ 140$ and $\$ 4$ million, 
respectively, against \$ 60 and \$ 2 million, respectively, in the preceding financial year.

Financial crisis: As of January 2009, Subhiksha has been facing severe financial crises pertaining to liquidity. This has led to the shutting down of a large number of stores across the Nation. It closed down 90 stores in one month (Chaurasia, 2008) i.e. during November 2008. Today, the company is on the threshold of a closure-it has no money to run its operations, its senior staff are deserting, many of its stores have reportedly been looted and the government may initiate an independent audit of accounts at the instance of ICICI Ventures, the second-largest shareholder with $23 \%$ stake (Krishna, 2009).

Analysts, however, agree that Subhiksha's low-cost model was sound. They blame the company's troubles on its rapid expansion with debt capital to open 800 stores in a year. Although the same store sales were as high as $\$ 250 \mathrm{ft}^{-2}$ during the first few months of 2008 , the debt taken on a number of new stores and the financial crisis put paid to Subhiksha's exuberance. The industry average for stores of $2000 \mathrm{ft}^{2}$ (Subhiksha's typical store size) to break even is $\$ 100 \mathrm{ft}^{-2}$ and analysts say that Subhiksha's new stores never achieved break-even levels (Krishna, 2009).

On 10th March, 2009 the regional office of the Employees Provident Fund Organization decided to attach the bank accounts of struggling Subhiksha Trading Services for failing to deposit PF dues even after the expiry of the deadline for doing so. Mr. R. Subramanian will need to pay $\$ 3.25$ million immediately in provident fund dues. There are reports that the Employee Provident Fund Office (EPFO) in Chennai would attach the properties of Subramanian for collection of dues and that the PF commissioner has begun a 7-A enquiry for determining the EPF dues of Subhiksha. It is further learnt that the company is unable to pay salaries and arrears to its 15000 employees from October 2008.

The revival plan: Mr. R. Subramanian has, however, not given up. Firm in the belief that Subhiksha can still be a viable business, he is making a last-ditch effort to survive by pitching for a $\$ 60$ million loan from a consortium of 13 banks, besides attempting a debt restructuring exercise. In a letter sent to $\mathrm{BW}$, Subramanian says, "The infusion of $\$ 60$ million would revive Subhiksha soon". That would allow him to pay off the vendors and resume operations at a minimal level, though he might also have to shell out a significant chunk of his 59\% stake. Subramanian's confidence stems from his belief that his business model is viable. "We did not raise enough equity and we paid the price", he says. "It was a capital structure problem rather than a business model problem".

The Corporate Debt Restructuring cell, a voluntary organization backed by the RBI assisting lenders and borrowers, began working on Subhiksha's debt from February. CDR involves a viability analysis followed by the restructuring of existing loans and the infusion of fresh loans. Officials said it was the first CDR in the service segment and given the large number of banks and the amount involved, it would set a standard for restructurings in the service industry.

Twelve of the 13 lender banks along with the three major shareholders of Subhiksha are working on the $\$$ 160 million debt restructuring program and ways to infuse funds into the company to revive operations. The contours of the revival plan have been agreed Only Kotak Mahindra Bank-which is one of the smallest lenders-chose to go legal. The remaining 12 banks, including the six which are part of a Corporate Debt Restructuring (CDR) process and the six others that are not part of CDR, have been working together on the revival package. The deadline for the closure of CDR is July 31, 2009 and the company is confident that the process will be completed well before that date.

Analysts feel that the $\$ 60$ million restructuring may help Subhiksha revive, but only if it closes at least $40 \%$ of its stores. That may keep it afloat, but would be disastrous for a company that fundamentally offers low prices and relies heavily on high volumes for better discounts from consumer companies.

\section{CONCLUSION}

Approximately 10-years of operation of Viswapriya by Mr. R. Subramanian saw it culminate into closure, however, without any disaster. Another 10 -years of operation of his second venture i.e., Subhiksha is heading for closure with many controversies surrounding it. Both the ventures were pioneering in their respective industries. Both these set the trends for many more to join. Both of it hit the great successes. Even though backed by class education from IIT and IIM (the pioneer institutions of technology and management in India), high philosophy of serving own people and Indian ethos, the Subramanian's Subhiksha (prosper) has become Iksha (perspire) today leaving minds of analysts stirred about what went wrong and where. Is it a case of strategic failure, that of financial bungling, or of mixed signals from Indian organized retail or ...? One thing is sure that in both his ventures, Mr. Subramanian cherished the upcoming markets and both the cases his ventures collapsed due to a sudden 
jerk in the industry. In the first case the external environment became unfavorable and lack of matching strategy made the venture crumble. In the second case it is the internal environmental factor that weakened the business and headed it towards the closure. Mr. Subramanian appears to have forgotten his own words, "If you don't do well here, you have only yourself to blame".

\section{REFERENCES}

Chaurasia, S., 2008. Shubiksha closes 90 retail stores. http://www.pluggd.in/indian-retailindustry/shubiksha-closes-90-retail-stores-3268/

Krishna, V., 2009. Subhiksha's Last Chance, Businessworld. http://www.businessworld.in/index.php/RetailFMCG/Subhikshas-Last-Chance.html
Vadlamani, S., 2009. Indian Retail in for a heady mix. http://trak.in/tags/business/2009/02/02/indianretail-in-for-a-heady-mix/\#comments

Venkataraman, S., 2007. Retail-setting store by the right model, Business Line. http://www.thehindubusinessline.com/iw/2007/07/ 22/stories/2007072250581500.htm

Warrier, S., 2007. Success Story of Subhiksha, India's largest retail chain.

http://www.rediff.com/cms/print.jsp?docpath=//mo ney/2007/feb/05bspec.htm 